\begin{tabular}{c} 
International Journal of Scientific World, $5(1)(2017) 5-8$ \\
International Journal of Scientific World \\
SPC \\
Website: $\begin{array}{c}\text { ww. sciencepubco.com/index.php/IJSW } \\
\text { doi: } 10.14419 / \text { ijsw. } v 5 i 1.6900 \\
\text { Research paper }\end{array}$ \\
\hline
\end{tabular}

\title{
Nutritional qualities assessment of locally processed spaghetti
}

\author{
Bitrus Wokhe Tukura*, Joseph Daniel Gbubele , Swaibatu Mamman \\ Department of Chemistry, Faculty of Natural and Applied Sciences, Nasarawa State University, Keffi, Nigeria \\ *Corresponding author E-mail: bittytukura@yahoo.com
}

\begin{abstract}
The quest for cheap and quality food is on the increase, especially during economy crises. Some nutritional properties of the raw and cooked local and industrial spaghetti were determined using standard methods. Concentrations of mineral elements were determined using atomic absorption spectrophotometer. Total ash $(0.98 \pm 007 \%)$, crude protein $(14.28 \pm 0.15 \%)$ and carbohydrate $(77.95 \pm 0.11 \%)$ levels in the raw industrial spaghetti were higher compared to the locally processed raw spaghetti. Carbohydrate and moisture levels for both processed spaghetti increased on cooking, while total ash and protein contents decreased. Crude fiber $(0.009 \pm 0.00 \%)$, carbohydrate $(77.52 \pm 0.21 \%)$ and moisture levels in the cooked local spaghetti were higher than in the cooked industrial spaghetti. Proximate contents of the local and industrial raw spaghetti were significantly $(P \leq 0.05)$ different. Concentrations of mineral elements in the raw locally processed spaghetti were lower than in the industrial spaghetti. Low levels of functional properties were recorded in the local spaghetti. Cooking decreased zinc content in the spaghetti, but significantly $(P \leq 0.05)$ increased the moisture content, crude fiber, carbohydrate and mineral contents. The spaghetti processed locally may serve as an alternative to the industrial spaghetti.
\end{abstract}

Keywords: Spaghetti; Processing; Cooking; Local; Industrial; Functional Semicolon.

\section{Introduction}

Spaghetti, like any other pasta product, is a stable food product that is produced mainly by mixing durum wheat semolina and water; and can be consumed after cooking as fresh pasta or dried for future use [1], [2]. Common pasta produced with wheat has better qualities, to include low cooking loss, firm pasta structure, and decreased adhesiveness [3]. Spaghetti is largely consumed by people across the continents. It is a popular food because of its sensory appeal, versatility, low cost, ease of preparation, excellent dried storage stability and strong nutritional image [4].

Spaghetti has a complex multi-component system consisting of bio-macromolecules such as proteins, carbohydrates and lipids [5]. Nutritionists consider spaghetti to be highly digestible, providing significant quantities of complex carbohydrates, low sodium and total fat [6]. However, it is low in dietary fiber, minerals and essential fatty acid [7], and a good source of carbohydrates (74$77 \%$,) with low glycemic index [8]. Foods rich in fiber aids weight control and reduce the risk of developing obesity [9].

Quality of spaghetti is usually influenced by the method use for its production. Eggs are sometimes added to industrially processed spaghetti to improve the nutritional quality and richness of the pasta. Small amount of optional ingredients, such as salt, celery, garlic, and bay leaf may also be added to pasta to enhance flavor. Disodium phosphate may be used to shorten cooking time [10]. Spaghetti is produced locally and consumed largely in the northern part of Nigeria, where it is known as Talia in Hausa language. Most traditionally processed spaghetti is devoid of ingredients. However, its relatively high patronage might be associating with low cost.

Foods are cooked by various methods, to include boiling. Cooking causes a series of physical and chemical changes in food. Foods that contain high levels of carbohydrates undergo caramelization process to produce the desirable flavor when cooked. Also, the heat can break the glycosidic bonds linking the glucose units together and effectively break-up the polysaccharides to release the glucose monosaccharide, which may impart natural sweetness to the food [11]. Processing makes food safe for consumption and destroys pathogenic microorganisms [12]. Cooking improves the digestibility of proteins and starch in foods, but there is inevitable leaching of nutrients into the cooking water that is sometimes discarded [13]. Researchers [3], [5], [14] have reported some information on spaghetti, nonetheless, information on the effects of processing and cooking on the nutritional qualities of industrial and locally manufactured spaghetti are scarce. The research was carried out to explore the effects processing and cooking on proximate and mineral compositions of locally processed spaghetti in comparison with the industrial manufactured spaghetti.

\section{Materials and methods}

\subsection{Sample collection and preparation}

The industrial spaghetti (Golden penny) and the wheat flour (Golden penny) used in processing the traditional spaghetti were purchased from Keffi market, in Keffi Local Government Area of Nasarawa State, Nigeria.

\subsection{Processing of local spaghetti}

Water $\left(75 \mathrm{~cm}^{3}\right)$ was added to 1 measure of the raw flour and then mixed using kitchen pasta makers. The sheet of the mixed flour was feed into the pasta machine by hand; and by turning a hand crank, the mixed flour was extruded through a machine comb that shape the flour mixture into the spaghetti shapes as they are extruded. The extruded spaghetti was then dried on a rope under shade for 4 hours before use. 


\subsection{Cooking of local spaghetti}

Cooking of the spaghetti was carried out according to AACC [15] $25 \mathrm{~g}$ portion of the spaghetti was added to $\mathrm{cm}^{3}$ of boiling water in a beaker. The pieces of spaghetti were stirred to separate while maintaining a rolling boil. The cooking water was maintained to at least $90 \%$ of its original volume. A piece of spaghetti was removed from the cooking water at 30 seconds interval and squeezed between two pieces of clean glass plates. Optimum cooking was established when the center white core could no longer be seen when a small piece was crushed between two glass plates.

\subsection{Proximate and mineral elements analysis}

Moisture, crude fiber, total ash and crude protein were determined according to the AOAC [16] method. The moisture content of the spaghetti samples was determined by oven-drying $\left(105^{\circ} \mathrm{C}\right.$ for 24 hr.), while total ash was quantified by dry-ashing $\left(550{ }^{\circ} \mathrm{C}\right)$. Crude fat was determined using Soxhlet extraction with hexane acting as the extraction solvent. The extract was evaporated $\left(105{ }^{\circ} \mathrm{C}\right)$ to a constant weight. Crude protein content was calculated from nitrogen $(\mathrm{N} \times 6.25)$ using the Kjeldahl method. Carbohydrate was calculated by difference [17]:

Carbohydrates $(\%)=100 \%-(\%$ crude protein $+\%$ crude lipid $+\%$ crude fiber $+\%$ total ash $+\%$ moisture $)$.

Processed spaghetti was digested with a mixture of concentrated nitric acid, sulphuric acid and perchloric acid according to AOAC [16] method, and then analyzed for mineral element contents using AAS.

\subsection{Determination of functional properties}

Water holding capacity and bulk density were determined using the methods reported by Vasantha and Narayanasamy [6]. The method of Coffman and Garcia [18] was adopted for the determination of foaming capacity and foaming stability of the flour and processed spaghetti.

\subsection{Statistical analysis of data}

Results were expressed as mean \pm SD. Significance differences ( $P$ $\leq 0.05)$ in the levels of the parameters were determined using one way analysis of variance (ANOVA). SPSS software (v. 20) was used for the analysis.

\section{Results and discussion}

\subsection{Proximate composition}

Proximate composition of the processed spaghetti (Table 1) indicated that moisture contents for the locally processed spaghett and wheat flour were $7.89 \pm 0.18 \%$ and $9.82 \pm 0.10 \%$ respectively, while that of the industrial spaghetti varied from $7.50 \pm 0.12$ (raw) to $7.66 \pm 0.16 \%$ (cooked). The values were similar to the results reported by Bashir et al. [19], and were within the range (11-13\%) required for pasta products [20]. Moisture contents varied in the order of flour > local-raw > industrial-raw. Low moisture content implies longer shelf life.

The ash contents of the raw $(0.98 \pm 0.07 \%)$ and the cooked $(0.93 \pm 0.04 \%)$ industrial spaghetti were higher than in the locally processed spaghetti. The values obtained were also within the range reported by Bashir et al. [19]. Crude protein contents in the raw $(14.28 \pm 0.15 \%)$ and cooked $(13.06 \pm 0.16 \%)$ industrially processed spaghetti were both higher than in the local spaghetti. The higher protein content of the industrial spaghetti might be due to added ingredients during production.
Crude fiber contents for both the raw $(0.004 \pm 0.00 \%)$ and cooked $(0.009 \pm 0.001 \%)$ spaghetti were higher in the local spaghetti, while crude fat levels were higher in the industrial spaghetti. Cooking increased and decreased the crude fiber and crude fat contents of the processed spaghetti respectively. Foods rich in fiber aids weight control and reduce the risk of developing obesity [9]. The relatively low crude fat content reported in all the samples will help in increasing the shelf life of the samples by decreasing the chances of rancidity [21].

Total carbohydrate content $(77.52 \pm 0.21 \%)$ was highest in the cooked locally processed spaghetti. Carbohydrate contents varied in the order of LR > IR > flour. Crude protein contents for the raw and the cooked industrial spaghetti were significantly $(\mathrm{P} \leq 0.05)$ different. Total ash content, crude protein and carbohydrate levels in the raw and cooked industrial and traditional spaghetti were significantly different $(\mathrm{P} \leq 0.5)$.

The processed spaghetti may be considered as good energy sources [22]. Moisture content, crude fiber and carbohydrate levels of the locally processed spaghetti increased on cooking, while ash contents, crude protein and crude fat levels decreased. The results agreed with the results reported for pasta products [8]. The decrease in ash content of foods is usually reflected by decrease in mineral contents. Cooked industrial spaghetti was more enriched with crude protein $(13.06 \pm 0.16 \%)$, fatty acid $(1.21 \pm 0.3 \%)$ and ash $(0.93 \pm 0.04 \%)$ contents.

Table 1: Proximate Composition (\%) of the Raw and Cooked Locally Processed and Industrial Spaghetti

\begin{tabular}{|c|c|c|c|c|c|}
\hline \multirow{2}{*}{$\begin{array}{l}\text { Para- } \\
\text { me- } \\
\text { ter }\end{array}$} & \multicolumn{2}{|l|}{ Local } & \multicolumn{3}{|l|}{ Industrial } \\
\hline & Flour & Raw & Cooked & Raw Coo & $\begin{array}{l}\text { Cooke } \\
\mathrm{d}\end{array}$ \\
\hline $\begin{array}{l}\text { Mois } \\
\text { t. }\end{array}$ & $\begin{array}{l}9.82 \pm 0.10 \\
\text { a }\end{array}$ & $\begin{array}{l}7.89 \pm 0.18 \\
b\end{array}$ & $\begin{array}{l}7.95 \pm 0.12 \\
b\end{array}$ & $\begin{array}{l}7.50 \pm 0.10 \\
b\end{array}$ & $7.66 \pm 0.10^{b}$ \\
\hline TA & $0.89 \pm 0.0^{\mathrm{a}}$ & $0.88 \pm 0.01$ & $\begin{array}{l}0.85 \pm 0.02 \\
\text { a }\end{array}$ & $0.98 \pm 0.07$ & $0.93 \pm 0.04^{\mathrm{b}}$ \\
\hline CP & $13.68 \pm 0.0$ & $\begin{array}{l}13.06 \pm 0.0 \\
4^{\mathrm{a}}\end{array}$ & $\begin{array}{l}12.65 \pm 0.1 \\
0^{\mathrm{b}}\end{array}$ & $\begin{array}{l}14.28 \pm 0.1 \\
5^{c}\end{array}$ & ${ }_{\mathrm{ab}}^{13.06 \pm 0.16}$ \\
\hline $\mathrm{CF}$ & $\begin{array}{l}0.003 \pm 0.0 \\
0^{\mathrm{a}}\end{array}$ & $\begin{array}{l}0.004 \pm 0.0 \\
0^{\mathrm{a}}\end{array}$ & $\begin{array}{l}0.009 \pm 0.0 \\
0^{\mathrm{a}}\end{array}$ & $\mathrm{ND}^{\mathrm{a}}$ & $\begin{array}{l}0.008 \pm 0.00 \\
\text { a }\end{array}$ \\
\hline Carb & $\begin{array}{l}74.40 \pm 0.2 \\
0^{\mathrm{a}}\end{array}$ & $\begin{array}{l}77.05 \pm 0.2 \\
5^{\mathrm{b}}\end{array}$ & $\begin{array}{l}77.52 \pm 0.2 \\
1^{\mathrm{b}}\end{array}$ & $\begin{array}{l}75.95 \pm 0.1 \\
1^{\mathrm{c}}\end{array}$ & $\begin{array}{l}77.13 \pm 0.20 \\
\text { b }\end{array}$ \\
\hline
\end{tabular}

\subsection{Mineral elements}

Mineral contents (Table 2) show that calcium (78.95-125.15 $\mathrm{mg} / 100 \mathrm{~g}$ ) and magnesium (35.01-35.76 $\mathrm{mg} / 100 \mathrm{~g}$ ) levels in the locally processed and industrial raw spaghetti were highest respectively. Concentration of copper $(0.33-0.55 \mathrm{mg} / 100 \mathrm{~g})$ was the lowest amongst mineral elements in the processed spaghetti. Copper assist in hemoglobin formation and contribute to iron and energy metabolism [23]. Zinc (2.18- $2.26 \mathrm{mg} / 100 \mathrm{~g})$ and iron (4.09 - 4.5 $\mathrm{mg} / 100 \mathrm{~g}$ ) contents were relatively low. Zinc plays a vital role in cell division, cell growth; fasten wound healing and breaking of carbohydrate content; while iron is necessary for the synthesis of hemoglobin, amino acid and protein [1]. The mineral contents of the locally processed raw spaghetti were generally higher compared to the industrial spaghetti.

The levels of minerals in the local and industrially processed spaghetti decreased and increased respectively on cooking. The decrease in mineral contents on cooking might be due to leaching of the minerals from the samples into the water. [8], [24]. Magnesium, iron and zinc contents were lower compared to the values reported by Ogunlakin et al. [25]. Mineral levels in the raw industrial and locally processed spaghetti were significantly different $(\mathrm{P}$ $\leq 0.05$ ), and also significantly higher than in the flour, except for $\mathrm{Fe}$ and $\mathrm{Mg}$. Cooking significantly $(\mathrm{P} \leq 0.05)$ decreased the mineral contents of both processed spaghetti. Calcium varied in the order of local-raw > industrial raw > wheat flour. Magnesium was the 
highest enriched mineral in the cooked spaghetti, while calcium the lowest.

Table 2: Average Levels of Mineral Elements (Mg/100g) in Locally Processed and Industrial Spaghetti

\begin{tabular}{llllll}
\hline Mineral & Local & & & \multicolumn{2}{c}{ Industrial } \\
Element & Flour & Raw & Cooked & Raw & Cooked \\
\hline $\mathrm{Cu}$ & $0.62^{\mathrm{a}}$ & $0.55^{\mathrm{b}}$ & $0.33^{\mathrm{c}}$ & $0.49^{\mathrm{b}}$ & $0.10^{\mathrm{d}}$ \\
$\mathrm{Zn}$ & $2.52^{\mathrm{a}}$ & $2.00^{\mathrm{b}}$ & $1.57^{\mathrm{c}}$ & $2.18^{\mathrm{b}}$ & $2.50^{\mathrm{ad}}$ \\
$\mathrm{Ca}$ & $65.89^{\mathrm{a}}$ & $125.15^{\mathrm{b}}$ & $\mathrm{ND}^{\mathrm{c}}$ & $78.95^{\mathrm{d}}$ & $\mathrm{ND}^{\mathrm{c}}$ \\
$\mathrm{Fe}$ & $4.56^{\mathrm{a}}$ & $4.09^{\mathrm{a}}$ & $1.33^{\mathrm{b}}$ & $4.59^{\mathrm{a}}$ & $4.73^{\mathrm{ac}}$ \\
$\mathrm{Mg}$ & $35.72^{\mathrm{a}}$ & $35.00^{\mathrm{a}}$ & $34.45^{\mathrm{b}}$ & $35.76^{\mathrm{a}}$ & $35.36^{\mathrm{a}}$ \\
\hline $\mathrm{ND}$ Not detected & & & &
\end{tabular}

\subsection{Functional properties}

The results of physicochemical properties of the processed spaghetti are presented in Table 3. The raw $\left(0.66 \pm 0.01 \mathrm{~g} / \mathrm{dm}^{3}\right)$ and cooked $\left(0.67 \pm 0.00 \mathrm{~g} / \mathrm{dm}^{3}\right)$ industrial spaghetti have higher bulk density compared to the locally processed spaghetti. The results obtained were lower than the values reported for formulated multi cereal composite mix [6]. Low bulk density is an indication that the volume of spaghetti would not decrease excessively during packaging, storage and distribution [26].

The lowest $(180.00 \pm 0.00 \mathrm{ml} / 100 \mathrm{~g})$ and the highest $(620.00 \pm 0.00$ $\mathrm{ml} / 100 \mathrm{~g}$ ) water holding capacities for the local spaghetti were recorded in the raw and the cooked spaghetti respectively; higher than the raw $(141.30 \pm 1.20 \mathrm{ml} / 100 \mathrm{~g})$ and cooked $(540.00 \pm 1.20$ $\mathrm{ml} / 100 \mathrm{~g}$ ) industrial spaghetti. Flour with high water holding capacity, have more hydrophilic constituents such as polysaccharides [25], [27]. Therefore, the higher water holding capacity for the cooked local and industrial spaghetti might be attributed to greater amount of hydrophilic constituents.

Foam stability and foam capacity are interrelated in its characteristics [6]. The foaming capacity $(14.37 \pm 0.02 \%)$ and foaming stability $(0.39 \pm 0.00-16.54 \pm 0.04 \%)$ levels at the different times $(0.0$ min. $-60 \mathrm{~min}$.) were higher in the raw industrial spaghetti. The increase observed in the raw spaghetti may be as a result of dry matter loss during processing, particularly carbohydrate, which caused an apparent increase in other nutrients such as protein. This variation may also account for the observed increase in protein concentration of the raw industrially processed spaghetti. The results were similar to the findings reported by [27]. The foaming capacity and foaming stability of both local and industrially processed spaghetti decreased on cooking while bulk density and water holding capacity increased.

Table 3: Some Functional Properties of the Locally Processed and Industrial Spaghetti

\begin{tabular}{llllll}
\hline $\begin{array}{l}\text { Para- } \\
\text { meter }\end{array}$ & \multicolumn{2}{c}{ Local } & & Industrial \\
& Flour & Raw & Cooked & Raw & Cooked \\
\hline BD & $0.48 \pm$ & $0.63 \pm$ & $0.64 \pm$ & $0.66 \pm$ & $0.67 \pm$ \\
$\left(\mathrm{g} / \mathrm{dm}^{3}\right)$ & 0.00 & 0.00 & 0.00 & 0.01 & 0.00 \\
WHC & $159.30 \pm$ & $180.00 \pm$ & $620.00 \pm$ & 141.30 & $540.00 \pm$ \\
$(\mathrm{ml} / 100 \mathrm{~g})$ & 1.20 & 0.00 & 0.00 & \pm 1.20 & 1.0020 \\
FC $(\%)$ & $9.77 \pm$ & $14.37 \pm$ & $10.33 \pm$ & $16.54 \pm$ & $14.19 \pm$ \\
FS (\%): & 0.01 & 0.02 & 0.03 & 0.04 & 0.03 \\
& & & & & \\
$0.0 \mathrm{~min}$ & $9.77 \pm$ & $14.37 \pm$ & $10.33 \pm$ & $16.54 \pm$ & $14.19 \pm$ \\
& 0.01 & 0.02 & 0.03 & 0.04 & 0.03 \\
$10 \mathrm{~min}$ & $2.73 \pm$ & $7.87 \pm$ & $5.40 \pm$ & $10.25 \pm$ & $9.06 \pm$ \\
& 0.01 & 0.03 & 0.01 & 0.04 & 0.03 \\
$30 \mathrm{~min}$ & $0.68 \pm$ & $3.32 \pm$ & $1.87 \pm$ & $2.46 \pm$ & $2.56 \pm$ \\
& 0.00 & 0.01 & 0.01 & 0.02 & 0.00 \\
$60 \mathrm{~min}$ & $0.20 \pm$ & $0.59 \pm$ & $0.30 \pm$ & $0.39 \pm$ & $0.59 \pm$ \\
& 0.00 & 0.00 & 0.01 & 0.00 & 0.01 \\
\hline
\end{tabular}

BD-Bulk density, WHC- Water holding capacity, FC- Foaming capacity, FS- Foaming stability.

\section{Conclusion}

Total ash, crude protein and carbohydrate contents were higher in the locally processed spaghetti compared to the raw flour. Mois- ture contents for both the raw and cooked industrial spaghetti were higher than in the local spaghetti. The processed spaghetti recorded the highest concentrations in calcium and magnesium. Cooking significantly $(\mathrm{P} \leq 0.05)$ increased the crude fiber and carbohydrate levels, but decreased the mineral contents and functional qualities of the processed spaghetti. The locally processed spaghetti may be patronized as an alternative to the industrial spaghetti.

\section{Acknowledgements}

The authors highly appreciate the management and laboratory staff of Science Development center, Sheda, Abuja, Nigeria, for providing the enabling environment for the success of the research work.

\section{References}

[1] Abou EAA, Helmy IMF, \& Bareh GF (2010), Nutrition evaluation and functional properties of chickpea (Cacerarietinum L.) flour and the improvement of spaghetti produced from its. J. Amer. Sci., 6(10): 1055 - 1062

[2] Khalid B, Vidhu A, \& Lubna M (2012), Physio-chemical and sensory characteristics of pasta fortified with chickpea flour and defatted soy flour. .IOSR J. Environ. Sci., Toxicol. Food Technol., 1(5): 34 - 39.

[3] Esmat AA, Helmy IMF, \& Bareh GF (2010), Nutritional evaluation and functional properties of Chickpea (Cicer arietinum L.) flour and the improvement of spaghetti produced. J. Amer. Sci., 6(10): $1055-1072$

[4] Cubadda RE, Carcia M, Marcouni E, \& Trivison MC (2007), Influence of gluten protein and drying temperature on the cooking of durum wheat pasta. Cereal Chem., 84(1): 48-55. https://doi.org/10.1094/CCHEM-84-1-0048.

[5] Kill RC (2001), Introduction in pasta and semolina technology. Blackwell Science LTD, London, U.K.

[6] Vasantha KP, \& Narayanasamy S (2013), Effect of processing techniques on the physical and nutritional properties of extruded product using multicereal composite mix. J. Environ. Sci. Toxicol. Food Technol., 5(4): 560 - 570 .

[7] Prabhasankar P, Genesa P \& Bhaskar N (2008), Influence of Indian brownseawed (Sargassummarginatum) as an ingredient on quality, biofunctional, and microstructure characteristics of pasta. Food Sci. Technol. Int., 15(5): 560 - 570.

[8] Mongel L, Cortassa G, Fiocchi F, Mussia G, \& Carta Q (1990), Glycoinsulinaemic response, digestion and intestinal absorption of starch contained in two types of spaghetti. Diabetes, Nutri. Metabol., 3: 239 - 246.

[9] Wardlaw GM, \& Hampl JS, (2007), Perspective in nutrition. $7^{\text {th }}$ ed. MaGraw Hill Companies, Newyork, U.S.A.

[10] Walsh DE \& Gill KA (1977). Pasta technology: element of food technology. ed. by Desrosier, N.W., AVI Publishing.

[11] Delwich J (2003), Handbook of flavour characterization. CRC Press.

[12] Okibe FG, Jubril B, Paul1ED, Shallangwa GA, \& Dallatu YA (2016), Effect of cooking methods on proximate and mineral composition of Fluted Pumpkin (Telfairia occidentalis) Leaves. Int. J. Biochem. Res. Rev., $9(2): \quad 1 \quad$ - 7. https://doi.org/10.9734/IJBCRR/2016/21483.

[13] Manthey FA, Yalla SR, Dick J, \& Badaruddin M (2004), Extrusion properties and cooking quality of spaghetti containing buckwheat bran flour. Cereal Chem., 81: 232 - 236. https://doi.org/10.1094/CCHEM.2004.81.2.232.

[14] Molina MR, Gudiel H, Baten MA, \& Bressani R (1982), Production of high protein quality pasta products using semolina/corn/soyflour mixture. Cereal Chem., 59: 34 - 37.

[15] American Association of Cereal Chemists (AACC) (1990), Approved methods of the AACC, $8^{\text {th }}$ ed. The association: St. Paul, MN.

[16] Association of Analytical Chemists (AOAC) (1999), Methods of analysis. Association of Official Analytical Chemists, Washington DC. U.S. 15,1250 - 1255.

[17] Bashir K, Aeri V, \& Masoodi L (2012), Physio-chemical and sensory characteristics of pasta fortified with chickpea flour and defatted soya flour. J. Environ. Sci. Toxicol. Food Technol., 1(5): 34 39. 
[18] Tukura BW \& Obika O (2014), Proximate and nutritional compositions of seeds of Breadfruit (Artocarpus altilis). IOSR J. Environ. Sci. Toxicol. Food Technol., 3(9): 68 - 73.

[19] Coffman CW, \& Garcia VV (1977), Functional properties of amino acid content of protein isolated from mung bean flour. J. Food Technol. Res., 473 - 484.

[20] Abdel-Aal ESM, \& Hucl P (2002), Amino acid composition and in vitro protein digestibility of selected ancient wheat and their product. J. Food Composition Analy, 15(6): 737 - 747 https://doi.org/10.1006/jfca.2002.1094.

[21] Arawande JO, Ajayi IO, \& Adewumi BL (2009), Nutritive significance of husked and dehusked seeds of African breadfruit and characterization of its extracted oil. J. Res.National Developt., 1(7): 345 $-347$.

[22] Adeyeye EI (2012), Determination of chemical composition of the nutritionally valuable part of male and female common West Africa fresh water crab (Sudanaute africanusafricanus). Int. Food Sci. Nutri, 53: 189 - 196. https://doi.org/10.1080/09637480220132805.

[23] Malik CP, \& Srivastave AK (1982), Textbook of plant physiology, New Dehli, India.

[24] Lucia P, Marcella M, Grazia S, \& Matteo AN (2011), Formulation optimization of gluten-free functional spaghetti based on maize flour and oat bran enriched in $\beta$-glucans. Materials, 4: 2119 - 2135. https://doi.org/10.3390/ma4122119.

[25] Ogunlakin GO, Oke MO, Babarinde G, \& Olatunbosun DG (2004), Effects of drying methods on proximate composition and physicochemical properties of Cocoyam flour. Amer. J. Food Technol. 7(4): 245-250. https://doi.org/10.3923/ajft.2012.245.250.

[26] Kaur M, \& Singh N (2005), Studies on functional, thermal and pasting properties of flours from different chickpea (Cicerarietinum L.) cultivars. Food Chem., 91: 403 - 411. https://doi.org/10.1016/j.foodchem.2004.06.015.

[27] Sozer N, Dalgic AC, \& Kaya A (2007), Thermal, textural and cooking properties of spaghetti enriched with resistant starch. J. $\begin{array}{lllll}\text { Food } & \text { Eng., } & \text { 81: } & 476 & -\end{array}$ https://doi.org/10.1016/j.jfoodeng.2006.11.026. 